\title{
PENGARUH MODEL PEMBELAJARAN SAINS TEKNOLOGI MASYARAKAT TERHADAP SIKAP ILMIAH DAN PRESTASI BELAJAR IPA PADA SISWA KELAS V SDN GUGUS BANYUNING
}

\author{
Ni Nyoman Lisna Handayani ${ }^{1}$, Ni Ketut Erna Muliastrini ${ }^{2}$ \\ ${ }^{1}$ STAHN Mpu Kuturan Singaraja, ${ }^{2}$ Universitas Pendidikan Ganesha \\ Coresponding author: Ni Nyoman Lisna Handayani \\ Email: lisnahandayani201@gmail.com
}

\begin{abstract}
This research aims to investigate the effect of Community-Science- Technology learning approach toward scientific attitude and science learning achievement on fifth grade students of public elementary school Banyuning Cluster. This research was a quasiexperiment with Posttest-Only Control-Group Design. Research population was 198 fifth grade students of Belantih cluster. Thirty three students were selected as sample which was determined using random sampling technique. Scientific attitude data were gathered using questionnaire and science learning achievement data were gathered using multiple choice test. Data were analyzed using MANOVA (Multivariate Analysis of Variance) assisted by SPSS 17.00 for windows. Research results show that: First, scientific attitude of students who followed Community-Science-Technology learning approach was significantly better than students who followed conventional learning. Second, science learning achievement of students who followed community-science-technology learning approach was significantly better than students who followed conventional learning. Third, simultaneously, scientific attitude and science learning achievement of students who followed community-sciencetechnology learning approach was significantly better than students who followed conventional learning. The results of this study are expected to provide information for educational institutions to take appropriate policies, which are related to efforts to develop scientific attitudes and improve student learning outcomes.
\end{abstract}

Keywords: community-science-technology, science learning achievement, scientific attitude.

Penelitian ini bertujuan untuk mengetahui besarnya pengaruh model pembelajaran sains teknologi masyarakat (STM) terhadap sikap ilmiah dan prestasi belajar IPA pada Siswa Kelas V SDN Gugus Banyuning. Penelitian ini adalah penelitian eksperimen semu dengan rancangan The Posttest-Only Control-Group Desain. Populasi penelitian adalah seluruh siswa kelas V gugus Banyuning dengan jumlah populasi 198 siswa. Sebanyak 33 siswa dipilih sebagai sampel yang ditentukan dengan teknik random sampling. Data sikap ilmiah dikumpulkan dengan kuesioner dan prestasi belajar IPA menggunakan tes pilihan ganda. Data dianalisis dengan menggunakan MANOVA (Multivariat Analysis of Variance) berbantuan SPSS 17.00 for windows. Hasil Penelitian menunjukkan bahwa: Pertama, sikap ilmiah antara siswa yang mengikuti model pembelajaran sains teknologi masyarakat secara signifikan lebih baik daripada siswa yang mengikuti pembelajaran konvensional (F sebesar 114,22 dan p < 0,05). Kedua, prestasi belajar IPA antara siswa yang mengikuti pembelajaran sains teknologi masyarakat secara signifikan lebih baik daripada siswa yang mengikuti pembelajaran konvensional (F sebesar 7,786 dan p < 0,05). Ketiga, secara simultan sikap ilmiah dan prestasi belajar antara siswa yang mengikuti model pembelajaran sains teknologi masyarakat secara signifikan lebih baik daripada siswa yang mengikuti pembelajaran konvensional (F sebesar 
$61,175$ dan $\mathrm{p}<0,05)$. Hasil penelitian ini diharapkan dapat memberi informasi bagi lembaga pendidikan untuk mengambil kebijakan yang tepat, yang berkaitan dengan upaya menumbungkembangkan sikap ilmiah dan meningkatkan hasil belajar siswa.

Kata kunci: Sains Teknologi Masyarakat, Sikap Ilmiah, Prestasi Belajar IPA.

\section{PENDAHULUAN}

Guru adalah salah satu unsur manusia yang sangat penting dalam proses pendidikan. Dalam proses pendidikan di sekolah, guru memegang tugas ganda yaitu sebagai pengajar danpendidik. Sebagai pengajar guru bertugas menuangkan sejumlah bahan pelajaran kedalam otak anak didik, sedangkan sebagai pendidik guru bertugas membimbing dan membina anak didik agar menjadi manusia susila yang cakap, aktif, kreatif, danmandiri. Baik mengajar maupun mendidik, itu merupakantugas dan tanggung jawab guru sebagai tenaga profesional.

Guru memegang peranan sentral dalam proses belajar mengajar, untuk itu mutu pendidikan di suatu sekolah sangat ditentukan oleh kemampuan yang dimilikiseorang guru dalam menjalankan tugasnya. Guru adalah faktor penentubagi keberhasilan pendidikan di sekolah, karena guru merupakan sentral serta sumberkegiatan belajar mengajar. Guru juga merupakankomponen yang berpengaruh dalam peningkatan mutu pendidikan di sekolah. Hal inimenunjukkan bahwa kemampuan atau kompetensi profesional dari seorang gurusangat menentukan mutu pendidikan.

Mengingat siswa sekolah dasar perkembangan kognitifnya masih berada pada tahap operasional konkret maka guru harus mampu merancang suatu pembelajaran yang mampu mengaktifkan siswa sehingga siswa akan termotivasi dalam pembelajaran. Dengan motivasi tersebut diharapkan prestasi belajar siswa dapat tercapai secara maksimal. Misalnya dalam suatu proses pembelajaran IPA di sekolah dasar, guru dapat membelajarkan siswa dengan merancang pembelajaran yang berorientasi pada belajar kelompok dan tes individu berupa kuis serta penghargaan sebagai pengakuan prestasi belajar yang dicapai. Tes individu berupa kuis merupakan hal yang menjadi tantangan bagi siswa dalam belajar karena dengan kuis tersebut siswa berkeinginan mendapatkan nilai yang tinggi. Dengan adanya penghargaan siswa akan merasa senang dan bersemangat belajar karena mereka akan mendapat imbalan akan prestasi belajarnya. Belajar kelompok, kuis dan penghargaan ini dapat memotivasi siswa dalam pembelajaran karena dilihat dari tahap perkembangannya, siswa sekolah dasar tidak terlepas dari hal yang menarik dan menyenangkan seperti kuis yang bersifat tantangan untuk mendapat nilai tinggi dan imbalan/penghargaan yang diberikan atas usahanya.

Makna belajar akan dirasakan secara langsung oleh siswa apabila materi yang diajarkan sesuai dengan tingkat kemampuan yang dimiliki dan dapat secara langsung diaplikasikan dalam kehidupan sehari-hari. Hal ini terkait dengan tingkat perkembangan anak usia SD yang masih dalam kategori operasional konkret. Hal ini berarti dalam memahami suatu materi pelajaran, siswa perlu dilibatkan secara aktif dalam proses belajar mengajar.

Proses pembelajaran IPA dewasa ini sudah cukup baik dengan penggunaan metode yang cukup menarik dalam pembelajaranya yang didukung dengan media yang cukup kreatif. Akan tetapi dalam kenyataannya di lapangan ada sebagian siswa yang kurang memiliki motivasi belajar dalam pembelajaran IPA karena kurang senang akan metode yang digunakan oleh gurunya dalam proses 
pembelajaran. Hal ini disebabkan karena metode yang digunakan dalam setiap proses pembelajaran IPA semuanya hampir sama dan metode tersebut tidak dipayungi dengan model pembelajaran yang kooperatif. Selain itu, kurangnya motivasi belajar sebagian siswa juga disebabkan karena kurang baiknya hubungan sosial antar siswa dalam satu kelas selama proses pembelajaran. Dalam kegiatan proses pembelajaran, metode yang diterapkan oleh guru belum mampu mengaktifkan siswa secara keseluruhan. Hal ini merupakan masalah yang harus dipecahkan oleh guru mata pelajaran karena kurangnya motivasi belajar siswa dalam proses pembelajaran akan dapat mempengaruhi tingkat prestasi belajar siswa tersebut.

Dari permasalahan tersebut, nampaknya dalam proses pembelajaran IPA perlu adanya model pembelajaran yang didukung dengan metode pembelajaran aktif yang dapat membangkitkan motivasi belajar siswa secara keseluruhan dalam satu kelas dan dapat menumbuhkan hubungan sosial siswa yang baik antar siswa dalam satu kelas dalam proses pembelajaran IPA serta dapat meningkatkan prestasi belajar siswa dalam mata pelajaran IPA. Model pembelajaran dapat diartikan sebagai suatu rencana atau pola yang digunakan dalam menyusun kurikulum, mengatur peserta didik dan memberi petunjuk kepada pengajar di kelas dalam setting pembelajara (Jihad \& Haris, 2008). Saat ini banyak dibicarakan tentang inovasi model pembelajaran dikalangan pendidikan. Ada banyak jenis inovasi model pembelajaran.

Stopsky \& Sharon (dalam Lasmawan, 2010:102) menyatakan bahwa masyarakat merupakan laboratorium dari Ilmu Pengetahuan Alam. Oleh karena itu, dalam setiap pembelajaran IPA seyogianya guru atau pendidik dapat merekonstruksi iklim sosial selama proses pembelajaran sehingga peserta didik dapat secara langsung melakukan aktifitas sosial, yang pada akhirnya pembelajaran akan lebih efektif dan bermakna. Hal senada juga dipaparkan oleh Bronwyn Cole\&Margit McGuire's (dalam Our Conversation with You about "Teaching Kids to Think", 2012) "masalah nyata dalam pembelajaran IPA adalah melibatkan pembelajar muda berpikir kreatif," menggambarkan bahwaanak kelaspertama dapatbergulat denganisu-isu yangbisa berkembangdi lingkungan merekajika mereka secara bersama-sama, mempertimbangkan bukti, disengaja, dan berkontribusi berpikir untuk diskusi.

Disisi lain yang dapat mempengaruhi proses pembelajaran adalah sikap ilmiah siswa. Sikap Ilmiahmerupakan salah satu aspek psikis siswa yang sangat penting untuk dipupuk dan dikembangkan. Potret pembelajaran IPA di SDN Banyuning ditemukan permasalahan yang sama dalam pembelajaran IPA. Sikap Ilmiah peserta didik sudah cenderung menurun. Gejala ini terlihat ketika proses pembelajaran dikelas, tidak semua peserta didikterlibat aktif dalam pembelajaran yang diakibatkan oleh kurangnya sikap Ilmiah dari peserta didik. Permasalahan lain yang ditemukan dalam pembelajaran IPA di SDN Banyuning yaitu selama pembelajaran IPA guru masih sebagai pusat pembelajaran dan hanya mengandalkan metode konvensional berupa ceramah dalam menyampaikan materi serta guru dan buku pelajaran sebagai sumber belajar siswa. Mata pelajaran IPA masih dianggap sebagai mata pelajaran yang menuntut kemampuan menghafal, tanpa perlu upaya pemahaman dan dikaitkan dengan permasalahan dalam kehidupan sehari-hari. Berbagai masalah dalam kegiatan belajar mengajar dikelas tentu akan berpengaruh pada prestasi belajar.

Dampak dari dominannya guru melaksanakan pembelajaran dengan menggunakan pembelajaran konvesional juga mempengaruhi minat belajar siswa. 
Minat belajar adalah aspek psikologi seseorang yang menampakkan diri dalam beberapa gejala, seperti: gairah, keinginan, perasaan suka untuk melakukan proses perubahan tingkah laku melalui berbagai kegiatan yang meliputi mencari pengetahuan dan pengalaman, dengan kata lain, prestasi belajar adalah perhatian, rasa suka, ketertarikan seseorang (siswa) terhadap belajar yang ditunjukkan melalui keantusiasan, partisipasi dan keaktifan dalam belajar.

Salah satu pembelajaran yang dapat diterapkan oleh guru untuk meningkatkan sikap ilmiah danprestasi belajar siswa adalah dengan menerapkan model pembelajaran STM. Dalam penerapannya,model pembelajaran STM dilaksanakan oleh guru melalui topik yang dibahas dengan jalan menghubungkan antara sains (Ilmu) dan teknologi yang terkait dengan kegunaannya di masyarakat. Dalam STM, pembelajaran harus dilakukan dalam konteks kebutuhan masyarakat dengan lebih dahulu menampilkan isu-isu di masyarakat berkaitan dengan topik yang akan dikaji atau dibahas (Sapriya, 2009:101).

Muslichach (2006) menyatakan bahwa model pembelajaran (STM) merupakan suatu model pembelajaran dalam pembelajaran IPA untuk mengembangkan kemampuan kepada siswa dalam menerapkan penegtahuan yang berasal dari konsep-konsep Ilmu, teknologi dan keterampilan yang berasal dari IPA teradap resolusi tentang isu-isu yang berkaitan tentang masalah Ilmu, teknologi dan masyarakat.

Poedjiadi (2005: 119) menyatakan bahwa, model pembelajaran STM menerapkan langkah-langkah pembelajaran dan pola pengorganisasian materi IPA sebagai berikut. Tahap pertama adalah apersepsi (apperception), dengan cara menyajikan materi-materi pengait untuk mengupayakan terciptanya kaitan-kaitan konseptual antara materi yang akan dibelajarkan dengan pengetahuan awal dan pengalaman yang sudah dimiliki siswa sebelumnya. Pemberian apersepsi dimaksudkan untuk menjembatani pemahaman awal siswa terhadap materi yang akan mereka pelajari. Tahap kedua adalah mengemukakan isuisu atau masalah aktual yang ada di masyarakat dan dapat diamati peserta didik. Juga bisa digali dari pendapat siswa dan dikaitkan dengan konsep yang akan dibahas, tahap ini disebut inisiasi, apersepsi, invitasi, atau eksplorasi. Tahap ketiga adalah pembentukan konsep, yaitu siswa membangun atau mengkonstruksi pengetahuan sendiri melalui observasi, eksperimen, dan diskusi. Tahap keempat adalah aplikasi konsep atau penyelesaian masalah, yaitu menganalisis isu/masalah yang telah dikemukakan di awal pembelajaran berdasar konsep yang telah dipahami siswa. Tahap kelima adalah pemantapan konsep, dimana guru memberikan sikap ilmiahlagar tidak terjadi kesalahan konsep pada siswa. Tahap keenam adalah evaluasi, dapat berupa evaluai proses maupun evaluasi hasil.

Hasil penelitian ini diperkuat oleh penelitian yang dilakukan oleh Yanto Budhi Raharjo pada tahun pelajaran (2017) dengan judul penelitian "Pengaruh Model Pembelajaran Sains, Teknologi, Masyarakat, dan Lingkungan (STML) Terhadap Keterampilan Berpikir Kreatif dan Sikap Ilmiah Siswa", ditemukan bahwa terdapat perbedaan keterampilan berfikir kreatif yang signifikan antara kelompok siswa yang belajar dengan model pembelajaran Sains-TeknologiMasyarakat (MPSTM) dibandingkan dengan kelompok siswa yang belajar denagn pembelajaran konvensional.

Mengacu pada temuan dan uraian di atas, terbukti bahwa model pembelajaran Sains-Teknologi-Masyarakat (STM) lebih efektif dibandingkan dengan pembelajaran konvensional untuk meningkatkan kemampuan berpikir kreatif. Hal ini tidak terlepas dari proses pembelajaran yang dilasanakan, namun hal 
yang tidak kalah pentingnya adalah memberi kesempatan seluas-luasnya kepada siswa untuk menuangkan ide-ide kreatifnya dalam memecahkan permasalahan. Hasil dari proses belajar ini akan membiasakan siswa untuk berfikir dari segala dimensi sehingga dalam memecahkan masalah akan lebih matang untuk memutuskan sesuatu tentang langkah apa yang sebaiknya diambil untuk memecahkan masalah tersebut.

Berdasarkan dari paparan yang telah dikemukakan dan temuan yang ada, penulis meyakini bahwa dengan model pembelajaran STM dapat memberikan peluang yang besar untuk mengembangkan segala potensi yang ada pada diri siswa, model ini sekaligus mengajak pendidik untuk mendidik dengan cara tepat, menyenangkan, dan mengesankan. Atas dasar ini, dibutuhkan pembuktian secara lanjut dengan melakukan penelitian lebih jauh mengenai pengimplementasian model pembelajaran STM guna meninjau seberapa besar pengaruhnya terhadap sikap silmiah dan prestasi belajar IPA siswa kelas $\mathrm{V}$ pada mata pelajaran IPA di Sekolah Dasar Gugus Banyuning.

\section{METODE}

Penelitian ini merupakan penelitian eksperimen semu (quasi eksperiment), dengan rancangan The Posttest-Only Control-Group Desain. Menurut Sugiyono (2012:72) penelitian eksperimen dapat diartikan sebagai metode penelitian yang digunakan untuk mencari pengaruh perlakuan tertentu terhadap yang lain dalam kondisi yang terkendalikan.

Populasi adalah wilayah generalisasi yang terdiri atas objek, subyek yang mempunyai kualitas dan karakteristik tertentu yang ditetapkan oleh peneliti untuk dipelajari dan kemudian ditarik kesimpulannya Sugiyono (2012:80). Selanjutnya Sugiyono juga menjelaskan sampel merupakan bagian dari jumlah dan karakteristik yang dimiliki oleh populasi. Populasi dan sampel dalam penelitian ini adalah siswa kelas kelas V SDN gugus Banyuning yang seluruhnya berjumlah 198 orang siswa. Sampel penelitian berjumlah 33 orang siswa yang diperoleh dengan melakukan uji kesetaraan pada masingmasing kelas terlebih dahulu. Uji kesetaraan dilakukan dengan menggunakan program SPSS 17.00 for windows dengan taraf signifikansi $5 \%$. Berdasarkan hasil uji kesetaraan diperoleh SDN 1 Banyuning sebagai kelompok eksperimen dan SDN 4 Banyuning sebagai kelompok kontrol.

Menurut Sugiyono (2012) variabel penelitian pada dasarnya merupakan segala sesuatu yang berbentuk apa saja yang ditetapkan oleh peneliti untuk dipelajari sehingga diperoleh informasi tentang hal tersebut, kemudian ditarik kesimpulannya. Variabel bebas adalah variabel yang mempengaruhi atau menjadi sebab perubahan variabel terikat. Variabel bebas dalam penelitian ini adalah pembelajaran dengan model pembelajaran STM. Sedangkan variabel terikat adalah variabel yang dipengaruhi atau yang menjadi akibat karena adanya variabel bebas. Variabel terikat dalam penelitian ini adalah sikap ilmiah dan prestasi belajar IPA.

Data pada penelitian ini dikumpulkan dengan metode pengumpulan data yang disesuaikan dengan tuntunan data dari masing- masing rumusan permasalahan. Berkaitan dengan permasalahan yang dikaji pada penelitian ini maka ada dua jenis data yang diperlukan yakni sikap ilmiah dan prestasi belajar IPA siswa. Oleh karena itu, data penelitian sikap ilmiah dan prestasi belajar IPA yang diperoleh harus valid dan reliabel.

Data sikap ilmiah dalam pembelajaran IPA dikumpulkan menggunakan kuesioner. Aspek sikap ilmiah yang diukur diantaranya sikap jujur, terbuka, toleran, skeptis, optimis, pemberani, dan kreatif. Data prestasi belajar IPA dikumpulkan dengan memberikan tes prestasi balajar IPA dalam 
bentuk pilihan ganda dengan empat pilihan (option).

Penelitian ini menggunakan instrumen sesuai dengan jenis dan sifat data yang dicari. Kisi- kisi instrumen yang dibuat dengan mempertimbangkan karakteristik tiap data. Penyusunan kisikisi yang disusun untuk menjamin kelengkapan dan validitas instrumen. Kisikisi instrumen sikap ilmiah dibuat sendiri oleh peneliti dengan mengacu pada grand teori sikap ilmiah pada materi pembelajaran IPA kelas $\mathrm{V}$ Gugus Banyuning. Kisi- kisi instrumen prestasi belajar IPA berpedoman pada landasan kurikulum yang menyangkut tentang standar kompetensi, kompetensi dasar, aspek materi dan indikator pembelajaran.

Sebelum instrumen ini digunakan maka dilakukan uji validitas isi dan reliabilitas. Untuk menentukan validitas isi (content validity) dilakukan oleh judges. Instrumen yang telah dinilai oleh judgis selanjutnya diuji cobakan di lapangan. Tujuan dari pengujicobaan intrumen adalah untuk menentukan validitas dan reliabilitas instrumen, tingkat kesukaran dan daya beda pada instrumen sikap ilmiah dan prestasi belajar IPA.

Uji coba validitas pada variabel sikap ilmiah dengan jumlah tes 20 butir dan jumlah sampel 60. Hasil penelitian dengan program microsoft excel pada taraf signifikansi $5 \%$ semua butir soal dinyatakan valid dengan reliabilitas 0,92 . Uji coba validitas pada variabel prestasi belajar IPA dengan jumlah tes 40 butir dan jumlah sampel 60. Hasil penelitian dengan program microsoft excel pada taraf signifikansi $5 \%$ adalah 2 soal dinyatakan gugur dan 38 dinyatakan valid dengan reliabilitas 0,84 . Soal yang dinyatakan gugur dibuang. Data yang sudah dikumpulkan ditabulasi rerata dan simpangan baku menyangkut data motivasi dan prestasi belajar IPA siswa. Analisis statistik yang digunakan untuk menguji hipotesis adalah menggunakan teknik MANOVA dengan taraf signifikansi 0,05 berbantuan SPSS 17.00 for windows.

\section{HASIL DAN PEMBAHASAN}

Deskripsi data dikelompokakan untuk menganalisis kecendrungan pertama motivasi belajar yang mengikuti pembelajaran model pembelajaran STM. Kedua prestasi belajar IPA yang mengikuti pembelajaran dengan menggunakan model pembelajaran STM. Ketiga motivasi belajar yang mengikuti pembelajaran konvensional. Keempat prestasi belajar IPA yang mengikuti pembelajaran konvensional. Rekapitulasi hasil perhitungan skor keempat variabel dapat dilihat pada pada Tabel 01 berikut.

Tabel 01 Rekapitulasi Hasil Perhitungan Skor Motivasi Belajar dan Prestasi Belajar IPA

\begin{tabular}{lcccc}
\hline Statistik & A1Y1 & A2Y1 & A1Y2 & A2Y2 \\
& & & & \\
\hline Mean & 83,22 & 70,66 & 87,62 & 78,18 \\
\hline $\begin{array}{l}\text { Standar } \\
\text { Deviasi }\end{array}$ & 5,81 & 6,03 & 8,40 & 7,67 \\
\hline Varians & 33,73 & 36,35 & 70,57 & 58,80 \\
\hline Minimum & 82 & 69 & 78 & 65 \\
\hline Maksimum & 95 & 82 & 95 & 79 \\
\hline Jangkauan & 13 & 13 & 17 & 14 \\
\hline Keterangan & & & &
\end{tabular}

Keterangan :

A1Y1: Deskripsi Data Prestasi belajar Siswa yang Mengikuti Model pembelajaran STM

A2Y1: Deskripsi Data Prestasi belajar Siswa yang Mengikuti Pembelajaran Konvensional

A1Y2: Deskripsi Data Sikap ilmiah Siswa yang Mengikuti Model pembelajaran STM

A2Y2: Deskripsi Data Sikap ilmiah Siswa yang Mengikuti Pembelajaran Konvensional

Rata-rata skor prestasi belajar IPA siswa yang mengikuti model pembelajaran STM adalah 83,22 berada pada interval 81,92 87,07 , termasuk kategori sedang Rata-rata skor prestasi belajar IPA siswa yang mengikuti model pembelajaran 
onvensional adalah 70,66 berada pada interval 70,58 - 74,74 termasuk katagori tinggi. Rata-rata skor sikap ilmiah siswa yang mengikuti model pembelajaran STM adalah 87,62 berada pada interval 70 - 84 termasuk kategori tinggi. Rata-rata skor sikap ilmiah siswa yang belajar dengan model pembelajaran konvensional adalah 78,18 berada pada interval $70-84$ termasuk katagori tinggi.

Hasil uji normalitas sebaran data diuji dengan teknik Kolmogorov-Smirnov dan Shapiro-Wilk menggunakan bantuan SPSS 17.00 for windows memiliki angka signifikansi lebih besar dari 0,05. Maka, semua sebaran data menurut model pembelajaran berdistribusi normal.

Uji homogenitas secara bersamasama menggunakan uji Box' $M$ menghasilkan angka signifikansi sebesar 0,235 dan secara sendiri-sendiri dengan $u j i$ Levene's Test menghasilkan angka signifikansi sebesar 0,939 untuk variabel sikap ilmiah dan angka signifikansi sebesar 0,282 untuk variabel prestasi belajar IPA. Berdasarkan hasil analisis tampak bahwa angka signifikansi yang dihasilkan baik secara bersama-sama maupun sendiri-sendiri lebih besar dari 0,05 . Dengan demikian dapat disimpulkan bahwa matrik varian-kovarians terhadap variabel sikap ilmiah dan prestasi belajar IPA siswa adalah homogen.

$$
\text { Hasil penelitian analisis }
$$

MANOVA dengan berbantuan SPSS 17.00 for windows menunjukkan kemandirian belajar antara siswa yang mengikuti model pembelajaran mandiri secara signifikan lebih baik daripada siswa siswa yang mengikuti pembelajaran konvensional diperoleh nilai $\mathrm{F}$ sebesar 4,574dan $\mathrm{p}<$ 0,05 . Berdasarkan data hasil analisis tersebut, secara teoretis dapat dikatakan bahwa penggunaan model pembelajaran STM lebih baik dan efektif untuk melibatkan sikap ilmiah siswa dalam proses pembelajaran. Ini berarti penerapan model STM terbukti efektif karena sesuai dengan salah satu kelebihannya, yaitu metode ini mampu melatih siswa untuk memahami, mengingat, dan melatih peran yang dimainkan sehingga berkesan dengan kuat dan tahan lama dalam ingatan siswa. Hal itu akan melatih ingatan siswa menjadi tajam. Ingatan yang bagus akan membantu siswa untuk belajar dan mencapai hasil yang maksimal (Sagala, 2009).

Mengacu pada temuan dan uraian di atas, terbukti bahwa model pembelajaran STM lebih efektif dibandingkan dengan pembelajaran konvensional untuk meningkatkan kemampuan berpikir kreatif. Hal ini tidak terlepas dari proses pembelajaran yang dilasanakan, namun hal yang tidak kalah pentingnya adalah memberi kesempatan seluas-luasnya kepada siswa untuk menuangkan ide-ide kreatifnya dalam memecahkan permasalahan. Hasil dari proses belajar ini akan membiasakan siswa untuk berfikir dari segala dimensi sehingga dalam memecahkan masalah akan lebih matang untuk memutuskan sesuatu tentang langkah apa yang sebaiknya diambil untuk memecahkan masalah tersebut.

Proses pembelajaran seperti yang telah diuraikan di atas sesuai dengan model pembelajaran Sains-TeknologiMasyarakat (STM). Menurut model SainsTeknologi-Masyarakat (STM), proses pembelajaran bukan merupakan tempat memindahkan ilmu dari guru kepada siswa semata, melainkan sebagia tempat menemukan ide dan konsep untuk dapat digunakan untuk memecahkan masalahmasalah nyata yang akan dihadapi. Model pembelajaran STM dalam IPA pada dasarnya memberikan peserta didik kaitan antara ilmu, teknologi dan masyarakat serta melatih kemampun berpikir kreatif siswa dalam memecahkan masalahmasalah nyata.

Tujuan penelitian yang kedua adalah menguji pengaruh model pembelajaran STM versus model konvensional terhadap prestasi belajar IPA. Hasil uji hipotesis dalam penelitian ini menujukkan bahwa prestasi belajar IPA 
siswa yang mengikuti model pembelajaran STM secara signifikan lebih baik daripada siswa yang mengikuti pembelajaran konvensional diperoleh nilai $\mathrm{F}$ sebesar 112,556 dan $\mathrm{p}<0,05$.

Melihat data hasil penelitian tersebut, secara teoretis dapat dikatakan bahwa prestasi belajar IPA siswa yang mengikuti model pembelajaran mandiri lebih baik dari siswa yang mengikuti pembelajaran konvensional. Pelaksanaan pembelajaran mandiri menyebabkan perhatian guru lebih banyak secara langsung tercurahkan kepada siswa dan memberikan kesempatan yang lebih luas kepada siswa dalam berinteraksi dengan siswa lainnya. Pembelajaran mandiri menyebabkan siswa memiliki inisiatif, dengan atau tanpa bantuan orang lain, untuk menganalisis kebutuhan belajarnya sendiri, merumuskan tujuan belajarnya sendiri, mengidentifikasi sumber-sumber belajar, memilih dan melaksanakan strategi belajar yang sesuai serta mengevaluasi hasil belajarnya sendiri. (Nugraheni, 2007).

Mengacu pada temuan dan hasil penelitian yang relevan, terbukti bahwa pembelajaran mandiri lebih efektif dibandingkan dengan pembelajaran konvensional. Pembelajaran mandiri memberikan kebebasan bagi siswa untuk mengeksplorasi dan mengelaborasi pengetahuan yang dimiliki serta dapat memberikan konfirmasi terhadap pengetahuan baru yang mereka peroleh dimana siswa diajak untuk belajar dengan cara menyenangkan namun tetap fokus. Kemandirian belajar yang diikuti oleh peningkatan prestasi belajar akan lebih bermutu, asli dan tahan lama karena siswa mengalami secara langsung, aktif dan partisipatif dengan melibatkan perasaan, pikiran, dan ketrampilan sesui dengan tujuan pembelajaran IPA.

Tujuan penelitian yang ketiga adalah untuk mengetahui pengaruh model pembelajaran STM secara simultan terhadap kemandirian belajar dan prestasi belajar IPA siswa. Berdasarkan temuan ini maka hasil analisis dengan teknik MANOVA menunjukkan bahwa harga $\mathrm{F}$ hitung sebesar 105,6 untuk Pillae Trace, Wilk Lambda, Hotelling's Trace, Roy's Largest Root dari implementasi model pembelajaran STM lebih kecil dari 0,05. Artinya semua nilai Pillae Trace, Wilk Lambda, Hotelling's Trace, Roy's Largest Root signifikan. Dengan demikian, terdapat pengaruh penerapan model pembelajaran STM terhadap sikap sosial dan prestasi belajar IPA secara simultan pada siswa kelas V Gugus Banyuning.

Peningkatan hasil sikap sosial dan prestasi belajar IPA siswa dapat terjadi karena model pembelajaran pembelajaran STM menekankan pada konten (isi) dan konteks (lingkungan). Konten berkenaan dengan cara menyajikan materi ajar agar lebih mudah dipahami siswa sedangkan konteks mengkondisikan lingkungan belajar yang menarik dan mengesankan. Berdasarkan uraian tersebut, pembelajaran model pembelajaran STM cukup efektif diterapkan dalam pembelajaran IPA baik secara sendiri maupun secara simultan guna meningkatkan sikap sosial dan prestasi belajar siswa.

\section{PENUTUP}

Berdasarkan analisis dan pembahasan seperti yang telah diuraikan kesimpulan yang dapat diambil sebagai berikut.

Pertama, terdapat perbedaan signifikan prestasi belajar IPA kelas V SD antara siswa yang mengikuti pembelajaran menggunakan model STM dengan siswa yang mengikuti pembelajaran konvensional. Kedua, terdapat perbedaan signifikan sikap ilmiah antara siswa yang mengikuti pembelajaran menggunakan model pembelajaran STM dengan siswa yang mengikuti pembelajaran konvensional. Ketiga, terdapat perbedaan signifikan prestasi belajar IPA kelas V dan sikap ilmiah antara siswa yang mengikuti pembelajaran yang menggunakan model 
pembelajaran STM dengan siswa yang mengikuti pembelajaran konvensional.

Saran dari hasil penelitian ini guna peningkatkan kualitas pembelajaran IPA adalah sebagai berikut. Pertama bagi para pendidik (guru), penerapan model pembelajaran STM sangat dianjurkan dalam pembelajaran terutama untuk materi yang akan memiliki kebermaknaan jika pembelajarannya dilakukan secara interaktif. Kedua, pendidik perlu meningkatkan kreativitasnya dalam memilih model, pendekatan dan metode yang tepat dalam proses pembelajaran. Tidak ada salahnya untuk mencoba menerapkan berbagai model dan metode pembelajaran guna meningkatkan prestasi belajar dan sikap ilmiah siswa. Ketiga, mengingat manfaat model STM dalam pembelajaran telah terbukti secara empiris dan memberi kontribusi positif, kiranya perlu dilakukan penelitian lanjutan baik untuk mata pelajaran IPA maupun mata pelajaran lainnya sehingga dapat memperkaya pengetahuan dan dapat dijadikan acuan dalam proses belajar mengajar

\section{DAFTAR PUSTAKA}

Dantes, (2012). Metode Penelitian. Yogyakarta: Andi Yogyakarta.

Jihad, A., \& Haris, A. (2008). Evaluasi pembelajaran. Yogyakarta: Multi Presindo.

Muslichach. (2006). Penerapan Pendekatan Sains-TeknologiMasyarakat Dalam Pembelajaran Sains di Sekolah Dasar. Yogyakarta : Departemen Pendidikan Nasional.

Nugraheni, E. (2007). Student Centered Learning dan Implikasinya Terhadap Proses Pembelajaran. Jurnal Pendidikan.

Poedjiadi, Anna. (2005). Sains-TeknologiMasyarakat model Pembelajaran Kontekstual bermuatan Nilai. Bandung: PT. Remaja Rosdakarya.
Raharjo, Yanto Budhi. (2011). Pengaruh Model Pembelajaran Sains, Teknologi, Masyarakat, dan Lingkungan (STML) Terhadap Keterampilan Berpikir Kreatif Dan Sikap Ilmiah Siswa. Singaraja. Undiksha

Sapriya. (2009). Pendidikan IPA Konsep dan Pembelajaran. Bandung: PT. Remaja Rosdakarya Offset.

Sardiman, (2007). Interaksi dan Motivasi Belajar Mengajar. Jakarta: Raja Grafindo Persada.

Suastra, I Wayan. (2009). Pembelajaran Sains Terkini. Singaraja: Universitas Pendidikan Ganesha.

Sugiono, (2012). Metode Penelitian Kuantitatif Kualitatif dan $R \& D$. Bandung Alfabeta.

Sukardi, (2010). Evaluasi Pendidikan. Jakarta: PT. Bumi Aksara.

Suparman. (2010). Gaya Mengajar Yang Menyenangkan Siswa. Yogyakarta: Pinus Book Publisher.

Trianto. (2007). Model-Model Pembelajaran Inovatif Berorientasi Konstruktivistik. Jakarta: Prestasi Pustaka Publisher. 